\title{
Factors Associated with the Current State of Food Safety Knowledge and Practices among the 'Doi' Workers in Bogura, Bangladesh: A Cross-sectional Study
}

\author{
M. S. Kayshar, M. S. Arifin, M. M. Rana, S. S. Akter, M. N. Hossain, and M. F. Jubayer
}

\section{ABSTRACT}

'Doi,' or yogurt, is a traditional dairy product in Bangladesh. Bogura's 'Doi' is the most popular of all 'Doi' items throughout the country. The state of food safety in the 'Doi' business is of great concern because this product is consumed by a vast number of people. The current study aims to evaluate the food safety knowledge and practice of the 'Doi' workers in Bogura as well as the associated factors. In this cross-sectional study, 150 people participated voluntarily and answered a structured questionnaire. The final result showed that the current state of their food safety knowledge $(4.7 \pm 2.9$; scale $=15)$ and practices $(21.5 \pm 6.2$; scale $=60)$ was not satisfactory. It was also observed that level of education, job hours, and training experience all had a substantial impact on knowledge and practices. Participants with a high level of food safety knowledge had 5.5 times more desired food safety practices than their peers. Therefore, the current findings emphasize the need of food safety trainings, certification, and employing educated personnel in the 'Doi' sectors.

Keywords: dairy, food safety, food handlers, KAP, yogurt.

Submitted : October 19, 2021

Published : November 09, 2021

ISSN: $2684-1827$

DOI: $10.24018 /$ ejfood.2021.3.6.397

\section{S. Kayshar*}

Sylhet Agricultural University, Sylhet3100, Bangladesh.

(e-mail: mamunbau06@gmail.com)

M. S. Arifin

Bangladesh Agricultural University, Mymensingh-2202, Bangladesh.

(e-mail: srijonyou ${ }^{\circledR}$ gmail.com)

M. M. Rana

Hajee Mohammad Danesh Science and

Technology University, Dinajpur,

Bangladesh.

(e-mail: mmrsohan@gmail.com)

S. S. Akter

Sylhet Agricultural University, Sylhet-

3100, Bangladesh.

(e-mail: sukhy.sust ${ }^{@}$ gmail.com)

M. N. Hossain

United Nations (UN), Central African Republic.

(e-mail: nahid@un.org)

M. F. Jubayer*

Sylhet Agricultural University, Sylhet3100, Bangladesh.

(e-mail: fahadbau21@ hotmail.com)

*Corresponding Author

\section{INTRODUCTION}

Bangladesh has an eclectic collection of traditional food products which are well known for their unique taste and nutritional value and certainly, these products are very suitable for the global market. 'Doi' (Yogurt) of Bogura is one of them. 'Doi' is a completely fermented dairy product made from cow's milk or skim milk, with sugar or in some special cases without sugar. Generally, yogurt is regarded as ready-to-eat food that is regularly consumed around the world for energy production and good health [1]. It is a well-balanced diet that contains nearly all of the nutrients present in raw milk and is a strong source of probiotics [2]. Due to its physiological, nutritional, and beneficial properties, it is considered a highly demanded and widely accepted popular drink [3]. When people of Bangladesh think about any type of yogurt, the 'Doi' of Bogura comes first to mind and all over the country it is commonly recognized as 'Bogurar Doi' as it is the best in taste and quality. This product has 250 years of strong historical background behind its birth. It is anticipated that skilled artisans and the environment (weather, water, and soil) of Bogura which is favorable for producing good quality milk, are the reasons for the uniqueness of 'Doi' of Bogura.

The production and commercialization of Bogurar Doi in Bangladesh are rapidly growing on a regular basis along with its increasing demand and popularity. 'Doi' (Yogurt) is produced and consumed throughout the country, but 'Doi' of Bogura is the best in terms of taste and acceptance. Because of the inimitable savors and distinctive characteristics, the product has a huge possibility of capturing the global market. But various factors such as lack of research to extend the shelf-life of the product, inappropriate handling during processing, absence of a proper hygienic condition, and so on make this task quite difficult. In fact, the significance of food safety knowledge both from the producers' and workers' points of view in the processing of dairy products is inevitable. A study showed that the microbiological quality of the raw milk and 'Doi' samples collected from different regions of Bangladesh were not satisfactory because of their high bacterial loads and 
precaution is needed to the management of raw milk and yogurt [4]. On the other hand, milk and yogurt, are very susceptible to bacterial contamination and thus readily perishable [5]. Dairy products are also considered potentially hazardous if the processing occurs in nonconforming conditions. Thus, they are classified as a highrisk food commodity. Microorganisms from different sources including personnel, water, equipment, additives, and packaging materials can contaminate dairy products during processing [6]. As a result, milk and milk-derived products can contain a wide range of microorganisms and serve as implicated food vehicles of foodborne diseases. In the case of yogurt, it was found that in Nigeria yeast and mold are considered primary contaminants, and fungi thrive in acidic environments and multiply rapidly [7]. Another study reveals that Campylobacter, Brucella, Salmonella, Listeria monocytogenes, Escherichia coli, and Shigella are only a few bacteria that have the ability to contaminate different dairy products and may lead to death [8].

A fundamental prerequisite for human health is access to adequate safe food. Food contamination and adulteration have become serious public health concerns; hence, food safety is an unceasing public health issue today $[9,10]$. The risks of contaminated and unsafe food are substantial and responsible for many life-threatening diseases, ranging from diarrhea to different variants of cancer [10,11]. In Bangladesh, foodborne disease is considered an alarming problem because a growing number of consumers suffer from a variety of health problems by consuming adulterated food [12]. As food production operators are the first line of defense to provide safe food to consumers, the employees play a vital role in different stages of processing in preventing foodborne disease outbreaks. Lack of ample knowledge related to food safety can make the person handle the food in an improper way which results in producing unsafe food. Along with this, improper food handling techniques can lead to foodborne disease and contamination, which can harm consumers' health in the long run [13]. The study also discovered that a considerable percentage of foodborne diseases emerge as a result of workers' improper food handling practices and illness, and that these are the fundamental causes of foodborne disease outbreaks [14]. Therefore, ample knowledge regarding food safety issues and hygiene practices is very important for food industry personnel. However, in the current aspect of Bangladesh and for commercial food entities here, this is a matter of great concern. According to the author acquaintance, limited researches have been conducted on dairy farm workers and no research on food safety knowledge and hygiene practices among 'Doi' sector employees occurs in Bangladesh. To enable and facilitate the management of this important 'Doi' sector, we feel an urge to comprehend and evaluate the worker's current condition of food safety knowledge and practices. We believe that this study will support the higher management as well as the government to set standards and develop useful strategies to uphold Bangladesh's 'Doi' sector globally. Hence, the objectives of this present research were to evaluate the food safety knowledge and practices among the 'Doi' workers in the Bogura district of Bangladesh, as well as to determine the factors contributing to the current situation.

\section{METHODS}

\section{A. Study Place and Period}

The majority of 'Doi' producers operate within the Bogura city and surrounding areas. So, the current study was carried out in the Bogura district from January to May 2020. Almost all of Bogura's popular 'Doi' enterprises participated in the survey (22 in number). The first six months of the year are peak months for 'Doi' manufacturing, with the greatest number of workers employed in the related companies. When winter approaches, the amount of 'Doi' manufacture decreases, and the number of workers decreases as well. As a result, we chose the pick period for this study in order to interview as many workers as possible.

\section{B. Study Design and Data Collection}

A structured and self-administrated questionnaire was established for conducting the study. For convenience, two versions (English and Bengali) of the questionnaire were prepared. One hundred and fifty (150) people took part in the study. All respondents voluntarily participated in the ongoing study, and enough time (60 minutes) was granted to complete the questionnaire. The questionnaire came with a brief completion instruction explaining the purpose of the study as well as directions on how to fill it out. According to the signed consent, participation in this study remained confidential because a consent form was acquired with a signature from each respondent before the survey. A pilot study was conducted before the main work on 40 workers (chosen at random) to determine the clarity of the questions, time management, and consistency. The first section of the questionnaire was designed to collect demographic information. The second section of the questionnaire was designed to accumulate information about food safety knowledge and practices. There were 15 closed-ended questions in both the knowledge and practice sections. In the knowledge part, three possible response choices were presented (true, false, don't know), and practices (never $=0$, rarely $=1$, sometimes $=2$, often $=3$, always $=4$ ). The response options were chosen in this manner to restrict the likelihood of selecting the correct answer by chance. The scores were converted to 0 to 100 points. A score above $60 \%$ was considered a good score and below that was considered poor. The final score was computed by adding all of the correct answers together. Participants were considered eligible for the study if they met the following criteria: (i) they had direct contact with the process, (ii) they had at least 6 months of work experience in 'Doi' production, and (iii) they were free of any disability or sickness. The food safety knowledge score varied from 0 to 15 , with a score of 8 or above indicating a good level of knowledge and a score of less than 8 indicating a poor level of knowledge. On the other hand, the practices score varied from 0 to 60 , with scores below 30 indicating poor practices and scores 30 or higher indicating a satisfactory level of practice.

\section{Statistical Analysis}

SPSS (version 23.0) software was used to analyze the 
data. To summarize variables of relevance, descriptive statistics (e.g., response percentage, mean, and standard deviation) were employed. Analytical statistics, including bivariate analyses and multiple logistic regression models, were utilized to discover characteristics related to meat handlers' food safety knowledge and practices. The demographic variables were involved in both univariable (unadjusted) and multivariable (adjusted) logistic regression models, with the exception of gender and health certificates (which were eliminated because of the lack of variance in categories). Odds ratios with $95 \%$ confidence intervals (CI) were used to analyze the strength of the connection between independent variables (such as age and education level) and dependent variables (food safety knowledge and practice).

\section{Ethical Approval}

The ethical committee of Sylhet Agricultural University approved the design of the study. Respondents were also asked to provide informed consent. There was no use of personal information during the study. All data were kept on a password-protected computer that only the research team had access to.

\section{RESULTS}

\section{A. Demographic Characteristics}

Table I depicts the demographic profiles of the 'Doi' workers, where all 150 food handlers who participated in this study were men. The mean age of the respondents was 32 years $(\mathrm{SD}=9.6)$, with a range of 16 to 66 years. Almost one-fourth of those polled $(\mathrm{n}=33,22.0 \%)$ have no formal education. The highest number of respondents $(n=59$, $39.3 \%$ ) showed to have primary education. More than half of respondents $(\mathrm{n}=80,53.3 \%)$ had worked for more than 5 years; but none had food safety training and no health certificates. Most of the participants were helper $(\mathrm{n}=110$, $73.3 \%)$, and the rest were cooker $(n=40,26.7 \%)$.
TABLE I: DEMOGRAPHIC CHARACTERISTICS OF THE RESPONDENTS

\begin{tabular}{|c|c|c|c|}
\hline Variables & Categories & Frequency (n) & Percentage (\%) \\
\hline Gender & Male & 150 & 100 \\
\hline \multirow[t]{4}{*}{ Age (years) } & $<20$ & 12 & 8.0 \\
\hline & $21-30$ & 57 & 38.0 \\
\hline & $31-40$ & 59 & 39.3 \\
\hline & $>40$ & 22 & 14.7 \\
\hline \multirow[t]{2}{*}{ Field of work } & Cooker & 40 & 26.7 \\
\hline & Helper & 110 & 73.3 \\
\hline \multirow[t]{4}{*}{ Education } & No & 33 & 22.0 \\
\hline & Primary & 59 & 39.3 \\
\hline & Secondary & 39 & 26.0 \\
\hline & $\begin{array}{l}\text { Higher } \\
\text { secondary }\end{array}$ & 19 & 12.6 \\
\hline \multirow{3}{*}{$\begin{array}{l}\text { Work experiences } \\
\text { (years) }\end{array}$} & $<5$ & 70 & 46.7 \\
\hline & $5-10$ & 45 & 30.0 \\
\hline & $>10$ & 35 & 23.3 \\
\hline \multirow[t]{2}{*}{$\begin{array}{l}\text { Working hour } \\
\text { (hours) }\end{array}$} & $<8$ & 81 & 54.0 \\
\hline & $>8$ & 69 & 46.0 \\
\hline \multirow[t]{2}{*}{$\begin{array}{l}\text { Food safety } \\
\text { training? }\end{array}$} & Yes & 0 & 0 \\
\hline & No & 150 & 100.0 \\
\hline \multirow{2}{*}{$\begin{array}{c}\text { Health } \\
\text { certificate? }\end{array}$} & Yes & 0 & 0 \\
\hline & No & 150 & 100.0 \\
\hline
\end{tabular}

\section{B. Food Safety Knowledge and Its Associated Factors among 'Doi' Workers}

Table II summarizes the assessment of 'Doi' handlers' food safety knowledge. The majority of participants reported having a fair level of awareness of general hygiene and sanitary procedures in the workplace, such as washing hands before work (96\%), wearing gloves $(90 \%)$, and food storage knowledge (89.3\%). Almost all $(93.3 \%)$ of those polled either did not know or answered wrong regarding the food poisoning problem. Overall, the majority of respondents admitted to being unaware of specific foodborne diseases and pathogens. Approximately 98\% of respondents did not answer correctly or did not know much about environmental hygiene-product relationships, and pathogenic bacteria elimination. However, everyone seemed to be knowledgeable about cleaning the process area and equipment before production for safe operation.

TABLE II: FOOD SAFETY KNOWLEDGE OF THE RESPONDENTS

\begin{tabular}{lccc}
\multicolumn{1}{c}{ Knowledge statements } & $\begin{array}{c}\text { True, } \\
\mathrm{n}(\%)\end{array}$ & $\begin{array}{c}\text { False, } \\
\mathrm{n}(\%)\end{array}$ & $\begin{array}{c}\text { Don't know, } \\
\mathrm{n}(\%)\end{array}$ \\
\hline $\begin{array}{l}\text { Hand washing before starting work is required to reduce the risk of food } \\
\text { contamination }\end{array}$ & $144(96)$ & $0(0.0)$ & $6(4.0)$ \\
$\begin{array}{l}\text { Food poisoning is caused by pathogenic microorganisms } \\
\text { Food storage conditions can have potential effects on human health. }\end{array}$ & $10(6.7)$ & $3(2.0)$ & $137(91.3)$ \\
Eating and drinking in the work place increase the risk of food \\
$\begin{array}{l}\text { contamination } \\
\text { The yellow color of the creamy layer of milk can be caused by }\end{array}$
\end{tabular}


TABLE III. FACTORS ASSOCIATED WITH THE FOOD SAFETY KNOWLEDGE

\begin{tabular}{|c|c|c|c|c|c|c|}
\hline \multirow{2}{*}{ Variables } & \multicolumn{2}{|c|}{ Knowledge level } & \multirow{2}{*}{ p-value } & \multicolumn{2}{|c|}{ Odds ratio $(95 \% \mathrm{CI})$} & \multirow{2}{*}{ VIF } \\
\hline & good & poor & & unadjusted & adjusted & \\
\hline \multicolumn{7}{|l|}{ Age } \\
\hline$<20$ & $2(16.7)$ & $10(83.3)$ & \multirow{4}{*}{0.608} & reference & reference & \multirow{4}{*}{1.578} \\
\hline $21-30$ & $11(19.3)$ & $46(80.7)$ & & $1.19(0.36-3.82)$ & $0.80(0.18-3.26)$ & \\
\hline $31-40$ & $11(18.6)$ & $48(81.4)$ & & $1.13(0.34-3.65)$ & $0.18(0.18-3.82)$ & \\
\hline$>40$ & $6(27.3)$ & $16(72.7)$ & & $1.85(0.54-6.61)$ & $1.30(0.22-7.18)$ & \\
\hline \multicolumn{7}{|l|}{ Field of work } \\
\hline cooker & $9(22.5)$ & $31(77.5)$ & \multirow{2}{*}{0.377} & reference & reference & \multirow[t]{2}{*}{1.213} \\
\hline helper & $21(19.1)$ & $89(80.9)$ & & $0.76(0.41-1.35)$ & $1.55(0.63-3.80)$ & \\
\hline \multicolumn{7}{|l|}{ Education } \\
\hline no education & $4(12.1)$ & $29(87.9)$ & \multirow{4}{*}{0.111} & reference & reference & \multirow{4}{*}{2.427} \\
\hline primary & $11(18.6)$ & $48(81.4)$ & & $1.66(0.72-4.01)$ & $2.33(0.73-7.83)$ & \\
\hline secondary & $9(23.1)$ & $30(76.9)$ & & $2.17(0.84-5.25)$ & $1.84(0.53-6.60)$ & \\
\hline higher secondary & $6(31.5)$ & $13(68.5)$ & & $3.33(1.25-9.11)^{*}$ & $4.55(1.13-18.77)^{*}$ & \\
\hline \multicolumn{7}{|l|}{ Work experience } \\
\hline$<5$ & $12(17.1)$ & $58(82.9)$ & \multirow{3}{*}{0.337} & reference & reference & \multirow{3}{*}{1.368} \\
\hline $5-10 y$ & $9(20.0)$ & $36(80.0)$ & & $1.24(0.63-2.17)$ & $0.509(0.15-1.61)$ & \\
\hline$>10$ & $9(25.7)$ & $26(74.5)$ & & $1.66(0.83-3.34)$ & $9.33(1.93-15.10)^{* *}$ & \\
\hline \multicolumn{7}{|l|}{ Working hour } \\
\hline$<8$ & $9(11.1)$ & $72(88.9)$ & \multirow[b]{2}{*}{0.000} & reference & reference & \multirow{2}{*}{1.067} \\
\hline$>8$ & $21(30.4)$ & $48(69.6)$ & & $\begin{array}{c}3.88(2.08- \\
7.20)^{* * *}\end{array}$ & $6.09(2.61-13.02)^{* * *}$ & \\
\hline \multicolumn{7}{|l|}{ Food safety training } \\
\hline Yes & $5(62.5)$ & $3(37.5)$ & \multirow{2}{*}{0.000} & $\begin{array}{l}7.78(2.72- \\
22.46)^{* * * *}\end{array}$ & $8.96(2.15-27.32)^{* *}$ & \multirow[t]{2}{*}{1.055} \\
\hline No & $25(17.6)$ & $117(82.4)$ & & reference & reference & \\
\hline
\end{tabular}

On a scale of 15.0, the mean score for food safety knowledge was $4.7(\mathrm{SD}=2.9)$. About $20 \%(95 \%$ CI $15.7-$ 24.7) of the participants had knowledge about good food safety. Working hours per day $(\mathrm{p}<0.001)$, and food safety training ( $\mathrm{p}<0.001)$ were found to be significantly linked with food safety knowledge using the Chi-square test (Table 3). Table III contains the findings of multiple logistic regressions that predicted the factors related to high levels of food safety awareness among study participants. According to the adjusted regression model, respondents who had higher secondary education [adjusted odds ratio (AOR) = $4.55,95 \%$ CI 1.13-18.77], had a work experience of $>10$ years $(A O R=9.33,95 \%$ CI 1.93-15.10), worked for $\geq 8 \mathrm{~h}$ per day $(\mathrm{AOR}=6.09,95 \% \mathrm{CI} 2.61-13.02)$, and had food safety training $(\mathrm{AOR}=8.9695 \% \mathrm{CI} 2.15-27.32)$ were more likely to possess a good level of food safety knowledge compared to their counterparts.

\section{Food Safety Practices and Their Associated Factors among 'Doi' Workers}

Table 4 displays an evaluation of the food safety practices of the participants. Approximately half of those surveyed (46-48\%) indicated they ate, drank, and smoked in 'Doi' processing floors on occasion. Most of them (93.6\%) said they never or rarely donned the apron or wore a hair cover at work. More than half of those polled (53.5\%) said they worked while they had diarrhea on occasion (Table IV). We discovered a worrisome fact: very few people acknowledged washing their hands before touching items $(n=12,8 \%)$, washing hands after using the toilet $(\mathrm{n}=17,11.3 \%)$, and using sanitizer after washing hands $(n=4,2.7 \%)$.

The mean score of food safety practice was $21.5(\mathrm{SD}=$ 6.2) on a scale of 60.0. Merely $16.3 \%$ (95\% CI $12.3-20.7$ ) of the workers stated a good level of food safety practices (Table V). The number of hours worked per day $(\mathrm{p}<0.001)$, food safety training $(p=0.018)$, and level of food safety knowledge $(\mathrm{p}<0.001)$ were found to be significantly related with food safety practices (Table V). The findings from the multiple logistic regression analyses can be observed from table 5. According to adjusted regression analyses, the likelihood of getting a satisfactory level of practice were nearly 8.5 times greater among survey participants who worked 8 hours per day contrasted to those who worked 8 hours per day $(\mathrm{AOR}=8.47,95 \%$ CI 3.13-22.95). When compared to their counterparts, individuals with a high level of food safety knowledge had 5.5 times higher food safety practice $(\mathrm{AOR}=5.63,95 \%$ CI 2.29-13.81).

TABLE IV: FOOD SAFETY PRACTICES OF THE RESPONDENTS

\begin{tabular}{|c|c|c|c|c|c|}
\hline Practice statements & $\begin{array}{l}\text { Never, } \\
\mathrm{n}(\%)\end{array}$ & $\begin{array}{c}\text { Rarely, } \\
\mathrm{n}(\%)\end{array}$ & $\begin{array}{c}\text { Sometimes, } \mathrm{n} \\
(\%)\end{array}$ & $\begin{array}{l}\text { Often, } \\
\mathrm{n}(\%)\end{array}$ & $\begin{array}{c}\text { Always, } \mathrm{n} \\
(\%)\end{array}$ \\
\hline In the processing area, do you eat or drink anything? & $8(5.3)$ & $34(22.7)$ & $73(48.7)$ & $32(21.3)$ & $3(2.0)$ \\
\hline Do you wash your hands before and after touching raw and processed foods? & $52(33.5)$ & $8(5.2)$ & $40(25.8)$ & $38(25.3)$ & $12(8.0)$ \\
\hline Are you wearing wrist watch while you're working? & $29(18.7)$ & $32(20.6)$ & $32(20.6)$ & $19(12.7)$ & $38(25.3)$ \\
\hline Do you wear mask all the time while working in the production floor? & $74(47.7)$ & $49(31.6)$ & $23(14.8)$ & $1(0.7)$ & $2(1.3)$ \\
\hline Do you wash your hand every time you have a restroom break? & $24(15.5)$ & $45(29.0)$ & $42(27.1)$ & $22(14.7)$ & $17(11.3)$ \\
\hline Do you work in a condition when you have diarrhea? & $27(17.4)$ & $33(21.3)$ & $83(53.5)$ & $6(4.0)$ & $1(0.7)$ \\
\hline Do you wear a hair cover during work? & $113(72.9)$ & $7(4.5)$ & $26(16.8)$ & $2(1.3)$ & $2(1.3)$ \\
\hline Are you cutting your nails regularly? & $0(0.0)$ & $2(1.3)$ & $28(18.1)$ & $22(14.7)$ & $98(65.3)$ \\
\hline Do you always use the sanitizer after washing your hands? & $140(90.3)$ & $2(1.3)$ & $3(1.9)$ & $1(0.7)$ & $4(2.7)$ \\
\hline Do you smoke inside meat processing areas? & $29(18.7)$ & $9(5.8)$ & $69(44.5)$ & $32(21.3)$ & $11(7.3)$ \\
\hline Do you wear gloves during work? & $78(50.3)$ & $47(30.3)$ & $22(14.2)$ & $1(0.7)$ & $2(1.3)$ \\
\hline Do you wear an apron during work? & $143(92.3)$ & $2(1.3)$ & $1(0.6)$ & $2(1.3)$ & $2(1.3)$ \\
\hline $\begin{array}{l}\text { "Do you handle/process milk when you have cuts, wounds, bruises, or } \\
\text { injuries on your hands?" }\end{array}$ & $19(12.3)$ & $22(14.2)$ & $96(61.9)$ & 13 (8.7) & $0(0.0)$ \\
\hline Do you remove your work equipment when using the toilet? & $6(3.9)$ & $12(7.7)$ & $72(46.5)$ & $35(23.3)$ & $25(16.7)$ \\
\hline Do you properly clean the storage area before storing new products? & $9(5.8)$ & $6(3.9)$ & $45(29.0)$ & $43(28.7)$ & $47(31.3)$ \\
\hline
\end{tabular}


TABLE V: FACTORS ASSOCIATED WITH THE FOOD SAFETY KNOWLEDGE

\begin{tabular}{|c|c|c|c|c|c|c|}
\hline \multirow{2}{*}{ Variables } & \multicolumn{2}{|c|}{ Practice level } & \multirow{2}{*}{ p-value } & \multicolumn{2}{|c|}{ Odds ratio $(95 \% \mathrm{CI})$} & \multirow{2}{*}{ VIF } \\
\hline & good & poor & & unadjusted & adjusted & \\
\hline Age & & & & & & 1.588 \\
\hline$<20$ & $2(16.7)$ & $10(83.3)$ & 0.485 & reference & reference & \\
\hline $21-30$ & $8(14.0)$ & $49(86.0)$ & & $0.77(0.22-2.50)$ & $0.49(0.12-2.17)$ & \\
\hline $31-40$ & $12(20.3)$ & $47(79.7)$ & & $1.27(0.41-4.10)$ & $0.85(0.17-3.18)$ & \\
\hline$>40$ & $3(13.6)$ & $19(86.4)$ & & $0.78(0.20-3.12)$ & $0.32(0.05-2.19)$ & \\
\hline helper & $19(17.2)$ & $91(82.8)$ & & $1.04(0.53-1.82)$ & $1.11(0.40-3.03)$ & \\
\hline Education & & & & & & 1.748 \\
\hline no education & $3(9.0)$ & $30(91.0)$ & 0.057 & reference & reference & \\
\hline primary & $10(16.9)$ & $49(83.1)$ & & $2.22(0.77-6.26)$ & $2.43(0.72-8.44)$ & \\
\hline secondary & $8(20.5)$ & $31(79.5)$ & & $3.04(1.05-8.93)^{*}$ & $3.15(0.82-12.43)$ & \\
\hline higher secondary & $4(20.9)$ & $15(79.1)$ & & $4.33(1.35-13.95)^{*}$ & $2.48(0.55-11.13)$ & \\
\hline Working hour & & & & & & 1.144 \\
\hline$<8$ & $5(6.2)$ & $76(93.8)$ & 0.000 & reference & reference & \\
\hline$>8$ & $20(29.0)$ & $49(71.0)$ & & $7.10(3.30-15.22)^{* * *}$ & $8.47(3.13-22.95)^{* * *}$ & \\
\hline Food safety training & & & & & & 1.112 \\
\hline Yes & $3(37.5)$ & $5(62.5)$ & 0.018 & $3.36(1.16-9.73)$ & $1.29(0.29-5.74)$ & \\
\hline No & $22(15.5)$ & $120(85.5)$ & & reference & reference & \\
\hline Food safety knowledge & & & & & & 1.164 \\
\hline Good & $14(46.7)$ & $16(53.3)$ & 0.000 & $9.10(4.61-17.91)^{* * *}$ & $5.63(2.29-13.81)^{* * *}$ & \\
\hline Poor & $11(9.1)$ & $109(90.9)$ & & reference & reference & \\
\hline
\end{tabular}

\section{DISCUSSION}

In this current research, the features linked with food safety knowledge and practices among 'Doi' workers in Bogura, Bangladesh were evaluated. Consequently, 'Doi' handlers in this study had low food safety knowledge and practice. Respondents were, however, more aware of certain food safety issues than others within the particular areas. For example, the majority of responders were conscious that hand washing prior to work, wearing gloves and aprons, and thoroughly cleaning instruments reduce the hazard of food contamination. They were, however, less knowledgeable with high-risk food poisoning categories, as well as specific foodborne diseases and microorganisms. A survey of dairy workers in northern China found that they have low levels of knowledge but acceptable attitudes and behavior [15]. However, the Bogura 'Doi' workers' understanding of several pathogenic microorganisms differs from the study of Young [16]. In addition, a study of small-scale dairy producers in Tajikistan's urban and peri-urban areas indicated that the farmers were similarly unaware of the causal microorganisms [17].

In terms of food safety knowledge-related factors, our findings discovered that education, work experiences, and training were all strongly accompanying to food safety knowledge. According to our findings, 'Doi' handlers with higher secondary education and some form of food safety training were more likely to have a high level of food safety awareness. Some comparable studies conducted in China and Canada found that the educational level and professional relevant training of dairy and cheese handlers was substantially related to their level of knowledge and food safety practices [15], [16], [18]. 'Doi' handlers may be subjected to food safety issues such as washing hands, using gloves and aprons, proper cleaning of the instruments, and identifying the pathways through which milk may be contaminated during the handling process through education and professional training. As a result, people who have received more education and training may have a better grasp of food safety. This finding stresses the importance of increasing higher education in Bangladesh, as well as providing regular training for 'Doi' handlers. The great majority of 'Doi' employees stated that they had no food safety or hygiene training. Given the scarcity of 'Doi' handler training programs in Bangladesh, it is vital that all 'Doi' handlers get such food safety and hygiene training. 'Doi' handlers with more than ten years of experience were more likely to be informed about food safety. However, this conclusion contradicts a comparable study [19], which found no significant relationship between years of experience and food safety knowledge. According to our findings, having a high degree of food safety knowledge can lead to good food safety practices. This study discovered that people who were aware about food safety were 5.7 times more likely to practice food safety. These findings strongly suggest that raising food safety awareness is a key component of encouraging appropriate food handling practices (e.g., hygienic and safe 'Doi' production).

\section{CONCLUSION}

According to the current study, 'Doi' workers in Bogura, Bangladesh currently lack adequate food safety knowledge, and relevant practices are subpar. As a result, it is obvious that some efforts must be taken to improve their knowledge and habits. We discovered that educational status, food safety trainings, and working hours are all significantly related to their knowledge level, and that good food safety knowledge influences food safety practices. To some extent, employing educated people in the 'Doi' companies can overcome this problem. Furthermore, the companies must provide comprehensive food safety training to their personnel on a regular basis. In order to improve the competencies of 'Doi' workers of Bogura, this training 
program should be structured with specific guidelines that indicates the food safety and hygiene issues. This will necessitate the Bangladesh Food Safety Authority (BFSA) incorporating regular training sessions for dairy handlers into their main missions of regulating and managing the dairy industries. On the other hand, "Doi" enterprises must pursue multiple food safety certification systems like HACCP, ISO, HALAL etc. in order to make their products employable in worldwide markets. This 'Bogurar Doi' may be qualified for the geographical indication (GI) act as a traditional product with special attributes.

\section{ACKNOWLEDGMENT AND FUNDING}

This work was supported by the University Grants Commission (UGC) of Bangladesh. Beside this, we sincerely acknowledge the participation of the 'Doi' workers of different manufacturers in Bogura, Bangladesh.

\section{DECLARATION OF INTEREST}

We declare that there are no conflicts of interest.

\section{REFERENCES}

[1] J. A. Alli, A. Oluwadun, I. O. Okonko, O. E. Fagade, A. F. Kolade, and V. O. Ogunleye, "Microbial assessment and microbiological quality of some commercially prepared yoghurt retailed in Ibadan, Oyo State, Southwestern Nigeria." British Journal of Dairy Sciences, vol. 1, no. 2, pp 34-38, 2010.

[2] R. C. Chandan, and K. R. Nauth, Yogurt. In: Handbook of Animal Based Fermented Food and Beverage Technology. CRC Press, Boca Raton, FL, 2012, ch. 12, pp. 213-233.

[3] N. De, T. M. Goodluck, and M. Bobai. "Microbiological quality assessment of bottled yogurt of different brands sold in Central Market, Kaduna Metropolis, Kaduna, Nigeria." Int. J. Curr. Microbiol. Appl. Sci, Vol. 3, no. 2, pp. 20-27, 2014.

[4] G. A. Hasan, S. Parveen, and J. Sultana. "Microbiological quality analysis of raw milk and yogurt available in some selected areas of Bangladesh." International Journal of Innovative Research in Science Engineering and Technology, Vol. 5, no. 3, pp. 2855-2859, March 2016.

[5] K. Girma, Z. Tilahun, and D. Haimanot. "Review on milk safety with emphasis on its public health." World J Dairy Food Sci, vol. 9, no. 2, pp. 166-183, 2014.

[6] P. Papademas, and T. Bintsis. "Food safety management systems (FSMS) in the dairy industry: A review." International Journal of Dairy Technology, vol. 63, no. 4, pp. 489-503, 2010.

[7] S. B. Oyeleke, "Microbial assessment of some commercially prepared yoghurt retailed in Minna, Niger State." African Journal of Microbiology Research, vol. 3, no. 5, pp. 245-248, 2009.

[8] L. Gould, E. Mungai, and C. B. Behravesh. "Outbreaks attributed to cheese: differences between outbreaks caused by unpasteurized and pasteurized dairy products, United States, 1998-2011." Foodborne Pathogens and Disease, vol. 11, no. 7, pp. 545-551, 2014.

[9] F. K. Käferstein, Y. Motarjemi, and D. W. Bettcher. "Foodborne disease control: a transnational challenge." Emerging Infectious Diseases, vol. 3, no. 4 pp. 503-510, 1997.

[10] M. F. Jubayer, M. S. Kayshar, M. S. Hossain, M. N. Uddin, M. AlEmran, and S. S. Akter, "Evaluation of food safety knowledge, attitude, and self-reported practices of trained and newly recruited untrained workers of two baking industries in Dhaka, Bangladesh." Heliyon, vol. 6, no. 9, p.e05021, 2020.

[11] Y. Motarjemi, F. Käferstein, G. Moy, and F. Quevedo. "Contaminated weaning food: a major risk factor for diarrhoea and associated malnutrition." Bulletin of the World Health Organization, vol. 71, no. 1 pp. 79, 1993.

[12] R. Noor, and F. Feroz. "Food safety in Bangladesh: A microbiological perspective." Stamford Journal of Microbiology, vol. 6, no. 1, pp. 1-6, 2016.
[13] E. C. D. Todd, J. D. Greig, C. A. Bartleson, and B. S. Michaels. "Outbreaks where food workers have been implicated in the spread of foodborne disease. Part 3. Factors contributing to outbreaks and description of outbreak categories." Journal of Food Protection, vol. 70, no. 9, pp. 2199-2217, 2017.

[14] L. McIntyre, L. Vallaster, L. Wilcott, S. B. Henderson, and T. Kosatsky. "Evaluation of food safety knowledge, attitudes and selfreported hand washing practices in FOODSAFE trained and untrained food handlers in British Columbia, Canada." Food Control, vol. 30, no. 1, pp. 150-156, 2013.

[15] Y. Chen, H. Ji, L. J. Chen, R. Jiang, Y. N. Wu. "Food safety knowledge, attitudes and behavior among dairy plant workers in Beijing, northern China." International Journal of Environmental Research and Public Health, vol. 15, no. 1, pp. 63, January 2018.

[16] I. Young, S. Hendrick, S. Parker, A. Rajić, J. T. McClure, J. Sanchez, S. A. McEwen, "Knowledge and attitudes towards food safety among Canadian dairy producers." Preventive veterinary medicine, vol. 94. No. 1-2, pp. 65-76, April 2014.

[17] E. Lindahl, N. Sattorov, S. Boqvist, U. Magnusson, "A study of knowledge, attitudes and practices relating to brucellosis among small-scale dairy farmers in an urban and peri-urban area of Tajikistan." PloS One, vol. 10, no. 2, e0117318. February 2015.

[18] S. Le, W. Bazger, A. R. Hill, A. Wilcock, "Awareness and perceptions of food safety of artisan cheese makers in Southwestern Ontario: A qualitative study." Food Control, vol. 41, pp. 158-167, July 2014.

[19] D. G. Yenealem, W. W. Yallew, S. Abdulmajid, "Food safety practice and associated factors among meat handlers in Gondar Town: a Cross-Sectional Study." Journal of Environmental and Public Health, vol. 24, February 2020.

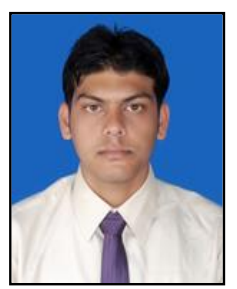

M. S. Kayshar, date of birth: 21/12/1988, place of birth: Rajshahi, Bangladesh, obtained his MS in Food Engineering (2012) and BSc Food Engineering (2010) from Bangladesh Agricultural University, Mymensingh, Bangladesh. He also completed his second master's degree in Food Identity under Erasmus Mundus scholarship from 2015 to 2017.

He is currently working as Assistant Professor in the Department of Food Engineering and Technology, Sylhet Agricultural University, Sylhet, Bangladesh. $\mathrm{He}$ has more than 15 scientific articles published in national and international journals that include research articles, correspondence, and short-communications. His research interests include food safety, food technology and product innovation, food policy, public health, and science of natural products and their derivatives.

M. S. Kayshar is a member of Krishibid Institution Bangladesh, a body for professional agriculturists in Bangladesh.

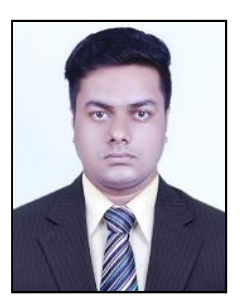

M. S. Arifin, date of birth: 01/01/1994, place of birth: Bogura, Bangladesh, obtained his MS in AgroIndustrial Chemistry (2018) and BSc in Agriculture (2016) from Bangladesh Agricultural University, Mymensingh, Bangladesh.

$\mathrm{He}$ is currently working as a part-time teacher and developing his own agro-farm. He has several scientific articles published in national and international journals. His research interests include food policy, agricultural chemistry, and agroindustrial production.

M. S. Arifin is a member of Krishibid Institution Bangladesh, a body for professional agriculturists in Bangladesh.

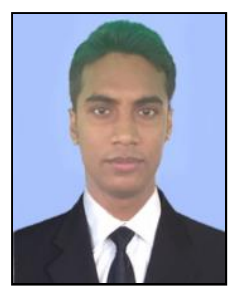

M. M. Rana, date of birth: 10/07/1994, place of birth: Natore, Bangladesh, obtained his MS in Food Engineering and Technology (2020) and BSc Food and Process Engineering (2017) from Hajee Mohammad Danesh Science and Technology University, Dinajpur, Bangladesh.

He is currently working as a Food Technologist in the PACE project by PKSF in Khagrachari, Bangladesh. He formerly worked as research fellow in different projects. He has several scientific articles published in national and international journals. His research interests include food technology, drying, and food processing. 


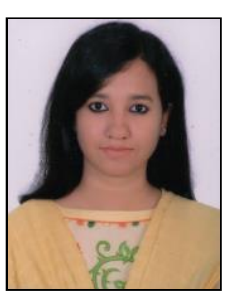

S. S. Akter, date of birth: 02/10/1991, place of birth: Sunamganj, Bangladesh, obtained her MS (Engineering) (2016) and BSc (Engineering) (2014) in Food Engineering and Tea Technology from Shahjalal University of Science and Technology, Sylhet, Bangladesh.

She is currently working as Assistant Professor in the Department of Food Engineering and Technology, Sylhet Agricultural University, Sylhet, Bangladesh. She has several scientific articles published in national and international journals. Her research interests include public health, food chemistry, food safety, food technology, medicinal plants, ethnic food.

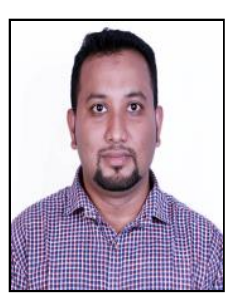

M. N. Hossain, date of birth: 01/04/1985, place of birth: Dinajpur, Bangladesh, obtained his MS in Food Engineering and BSc Food Engineering from Bangladesh Agricultural University, Mymensingh, Bangladesh. He is currently enrolled for a PGD in Supply Chain Management.

Presently, he is working with the United Nations peacekeeping mission in the Central African Republic (MINUSCA) as Rations Operations Assistant under the supply chain management. $\mathrm{He}$ also served for the same organization in a different role as Rations Assistant-Quality assurance from 2016-2018.

M. N. Hossain is professionally trained on procurement, supply chain management, logistics, contract management, food safety and quality (HACCP/GMP/GLP/ISO-22000/GFSI) to ensure the uninterrupted supply chain in a challenging environment such as in the mission area or in an unexpected emergency situation.

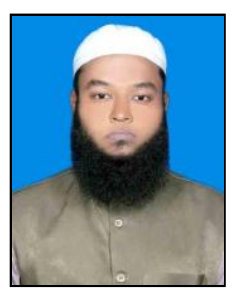

M. F. Jubayer, date of birth: 01/01/1991, place of birth: Bogura, Bangladesh, obtained his MS in Food Engineering (2014) and BSc Food Engineering (2012) from Bangladesh Agricultural University, Mymensingh, Bangladesh.

He is currently working as Assistant Professor in the Department of Food Engineering and Technology, Sylhet Agricultural University, Sylhet, Bangladesh. $\mathrm{He}$ formerly worked for Dan Cake Bangladesh as a Senior Quality Assurance Executive for long 2.5 years. He has more than 25 scientific articles published in national and international journals that include research articles, reviews, correspondence, short-communications, and book chapters. His research interests include food safety, food technology, medicinal plants, and public health.

M. F. Jubayer is a member of Krishibid Institution Bangladesh, a body for professional agriculturists in Bangladesh. 